\title{
Labour Law Limited to the Citizen? Considering Labour Migrants in the UK
}

\author{
Dr. Anastasia Tataryn \\ Lecturer in Law School of Law and Social Justice \\ University of Liverpool
}

Recibido: 12.05 .2016

Aceptado: 16.06 .2016

DOI: http://dx.doi.org/10.20318/sllerj.2016.3312

\begin{abstract}
The use of the term 'migrant' supports a particular construction of the legal subject of labour law, whereby the exclusion of some from recognition as 'citizen nationals' justifies exclusion from a formal employment relationship. Being outside of a formal employment relationship renders 'migrants' useful and necessary as precarious labourers in the current globalised economic market. This paper examines UK labour and migration law to raise theoretical questions underpinning a current crisis of labour law.

Keywords: labour migration, precarious labour, labour law in the UK, citizenship.
\end{abstract}

\section{Introduction to 'migrant workers'}

Labourers who are identified as migrants (foreign, non-nationals) elicit critical responses in media and political discourse. Most often, these are individuals working in low-waged, 'low-skilled' labour. Their status is deemed to be 'migrant' as a result of their actual nationality, country of citizenship or as a result of racial and ethnic prejudice. Moreover, persons working in 'bottom-end' labour, without permanent employment contracts and/or residency are also equated with holding irregular, or precarious, immigration status. Migration regarded as irregular, as opposed to illegal or undocumented, has raised concern in the UK both with regard to the exploitable and exploited situation of many of these persons when they are working, and the fear that foreign workers in non-specialised ('skilled') employment may be willing to work for less than British (nationals) workers and thus adversely affect the employment opportunities of British citizens. ${ }^{1}$ It is difficult to define precisely who are the individuals considered to be migrant labourers. Are these persons foreign nationals? Does their legal employment require a work permit or visa? Is their immigration status in the UK precarious, or at risk of becoming precarious? The label, migrant labourer is used to represent the ambiguous demographic that is seen to not hold per-

\footnotetext{
${ }^{1}$ CheRTI AND BRUhmie 2013, 1. Researchers have suggested that high irregular migration is due to the lack of regularisation programmes, which have been implemented in other EU countries, as well as a UK policy of returning migrants (deportation, and assisted voluntary return). Regularisation programmes are discussed in Linda Bosniak, 2013. Arguing for Amnesty Law Culture Humanities 9(3): 432-442. Commonly, in the UK it is reported that the public are 'opposed to immigration'. This statement raises a host of problems, which I will not detail here, except to highlight that the problematic demographic called 'irregular migrant labourers' may often not be actual migrants or persons with irregular/precarious immigration status, but either foreign-born nationals or citizens with the freedom of movement and work within the European Union. Scott Blinder at the Migration Observatory has looked at public opinion surveys and immigration discourses. Scott Blinder, 2012. Briefing: UK Public Opinion Towards Immigration: Overall Attitudes and Public Concern Migration Observatory Oxford: University of Oxford at 2, 6; Scott Blinder, 2012. Imagined Immigration: The Different Meanings of 'Immigrants' in Public Opinion and Policy Debates in Britain Centre on Migration, Policy and Society Oxford: University of Oxford. A further issue is the fear that migrants are taking advantage of British social services, for instance the NHS. However this is beyond the scope of my current discussion which will focus on the labour of persons considered to be migrant labourers.
} 
manent status and citizenship. The label, irregular migrant labour, including the ambiguity of both the terms 'irregular' and 'migrant', homogenise the diverse and multifaceted experiences of labourers and migrants, but also presumes a precarious legal status, albeit without the term 'illegal', thus making even the legality or illegality of their immigration and/or employment status questionable. ${ }^{2}$

The persons who may indiscriminately be identified as migrant labourers are subjected to intersectional discrimination and prejudice as result of their race, gender, and financial situation (poverty), ability, nationality, citizenship (or lack thereof), education, language and so on. Rather than trouble each of these discriminations and their manifestation in employment practices and labour markets, the title of 'migrant' lumps these differences as one experience against an ideal 'regular citizen'. The regular citizen is recognised as a legal subject in existing legal categories and traditional frameworks of labour law. However it is increasingly evident that this regular citizen-subject is, in current labour market practices, difficult to locate. This is in spite of the legal frameworks that demand persons to conform to this specific 'normal' legal subject to enable legal recognition and protection. In spite of this salient normative category, the migrant labourer has become a 'normal' labour market presence. Consequently, labour law is challenged to adapt to recognise the migrant as a part of an international, and national/domestic, labour market.

A 'migrant labourer' is not synonymous with outsider status. Migrants are not necessarily outside the system and the nation-state. Rather, the term 'migrant' effectively renders persons as lesser citizens, less-deserving and marginalised in a sub form of legal subjectivity while not denied subjectivity absolutely. The reliance on such elusive terms as the 'migrant', points to the limited extent that formal legal categories of citizenship and immigration status can identify the participation -residence and work or employment- of persons in the UK labour market who exceed standard categories of recognition. ${ }^{3}$

Persons may be in situations where they are not tangibly granted full status under the law, and their belonging as citizens in the nation-state is stunted. Notwithstanding the fact that holding legal citizenship status does grant the possibility of legal recognition where a lack of citizenship does not, marginalisation and exclusion from being considered a citizen legal subject may continue in spite of formal citizenship status. This is not as a result of legal barriers, which would be remedied by expanding legal categories and access to titles of citizenship. Rather, the ostensible exclusion is from what Anderson refers to as participation in the nation through a 'community of value'. ${ }^{4}$ The members of this community of value are the contrast to migrant. The community of value is the community of the non-migrant citizens. But who are these persons? By broadly referring to a migrant (racialised, ethnic) labour force, the the domestic citizen labour force is constructed as the norm, but in practice these are only those citizens with qualities un-hampered by race, gender, class, dis/ability and other discriminatory labels. According to Anderson, the community of value is comprised of persons who share values and form the national community, however in an elusive and slippery manner because these values are difficult to pinpoint and hold within a particular time and place. Nevertheless, the community of value is 'one of the ways the

\footnotetext{
${ }^{2}$ The term 'irregular' encompasses a spectrum of experiences in migration and labour. It can be used to refer to situations where individuals may slip into different immigration statuses however without being definitively identified as illegal and therefore subject to deportation and/or placed into detention. The spectrum of immigration status and ones movement on the spectrum may be a consequence of individuals' own actions, employers' actions, or legislative changes. It can be easy to fall in and out of status, for instance through sponsorship breakdown or if employed, as a migrant on a work permit, in very lowwaged labour. For instance, for many migrants in bottom-end labour it is necessary to supplement income with a second job in order to meet the cost of basic necessities nevermind send remittances to their home country. Falling in and out of status, the individual may be considered to be in an 'irregular' situation. Anderson, Ruhs. However, irregular migrants are not clearly illegal. Irregular statuses are much more difficult to tackle as a strict issue of legal enforcement. There is often ambiguity as to which legal measures apply to an individual's particular situation. 'Irregularity' involves a spectrum of precarious statuses or semi-compliance with law (MARTin RuHs and Bridget ANDERson. 2010. Semi-compliance and illegality in migrant labour markets: An analysis of migrants, employers and the state in the UK. Population, Space and Place 16 (3): 195-21). Irregular migrants may refer to irregular entrants, foreign-nationals exceeding their permission to stay or who do not abide by conditions of stay, or children of irregular migrants who do not have the leave to remain (Gordon and SCANLON 2009, 4-5). Due to the lack of empirical data and lack of specificity as to who and what is considered to be 'irregular' as well as 'migrant', irregular migration is heavily under-theorised (BOMmES and SCIORITINo 2011, 13).

${ }^{3}$ For instance, legal categories of citizen-national, naturalized immigrant, seasonal worker, or visa holders. Also non-legal categories that are based on racial, ethnic, socio-economic and gender identifications.

${ }^{4}$ ANDERSON 2013.
} 
state claims legitimacy' through shared (cultural) values; indeed the nation is a community of value at its best when populated by Good Citizens who are law-abiding and hard-working (economically productive) members of stable and respectable (nuclear) families. ${ }^{5}$ The Good Citizen ideal is the product of a liberal, Western, modern-colonial paradigm; moreover reinforced by a neoliberal free-market ideology. Qualities are of an individual, independent, autonomous, participate in the market economy, the political public sphere and are unhampered by the 'disabilities' of race, gender, class and so on.

As a legal status, national citizenship, identified through a passport or other national identity document, can facilitate the right to access social services, employment and legal representation. Symbolically citizenship facilitates belonging, identity and rights. Within the modern nation-state system the recognition of citizenship confers rights and obligations of persons within a sovereign nation of which they are considered to be a national. Through citizenship, sovereign states distinguish their national members from foreigners, and control access to rights accordingly. ${ }^{6}$ Thus, formal citizenship is more than a symbol of membership in a state; it is part of an international system where states bear the responsibility to admit and govern those they have accepted as their citizens. ${ }^{7}$ Citizenship under the law tends to universalise belonging, because it suggests that there is an attainable legal status for all persons within a territory. Meanwhile as above, citizenship is "characterised by inclusion and exclusion. ${ }^{8}$ However the inclusion and exclusion is not physical, but from membership which is troubled, or in practice defined, by the community of value. Citizenship closes off membership, meanwhile purporting to represent universalism. ${ }^{9}$ Furthermore, as mentioned above, membership in a nation-state through citizenship is not only a matter of legal techniques and requirements; it is based on conditions of desirability according to the community of value. These conditions make practical membership for some impossible, and they are therefore excluded from recognition in legal categories and, as will be discussed below, labour law frameworks. ${ }^{10}$ Bridget Anderson's Good Citizen - 'the liberal sovereign self: rational, self-owning, and independent, with a moral compass ${ }^{11}$ - overpowers formal citizenship status, such as guaranteeing rights as a consequence of nationality through a passport. In contrast, the Failed Citizen is dependent, transgressive, potentially criminal, and above all, an 'abnormal' outsider. There are many examples of citizenship being contested and/or experienced that complicate formal, legal, state-centric, interpretations of the term. In the UK in 2014, there was much debate about how to limit the citizenship rights of, or ban re-admittance to, British citizens who left the country to join the Syrian army and the army of the Islamic State. $^{12}$

Of interest to the application of labour law is how a domestic labour market suggests that its labour force is predominantly made up of citizen-workers. While the dominant community of value privileges economic participation in the public economic market, the UK labour force has always included the labour of those historically, and currently, not considered full citizens and furthermore excluded from the formal labour force and economic market: women, ${ }^{13}$ colonial subjects, slaves or indentured

\footnotetext{
${ }^{5}$ ANDERson 2013, 3.

${ }^{6}$ SASKIA SASSEN, "Globalisation or Denationalisation" Review of International Political Economy 10: 1 (2003): 1-22.

7 Bridget Anderson, "What does 'The Migrant' tell us about the (Good) Citizen?" Centre on Migration, Policy and Society Working Paper University of Oxford, 94 (2012), 1, 4.

${ }^{8}$ Margriet Kraamwinkel, “The Imagined European Community: Are Housewives European Citizens?"” In Labour Law in an Era of Globalisation: Transformative Practices and Possibilities, Joanne Conaghan, Richard M Fischl and Karl Klare, eds., 321-338 (Oxford: Oxford University Press, 2012), 323. Citizenship has been associated with political-economic participation that is based on a liberal, individual, male, property (land)-holding subject being recognised as a citizen of a political community, namely the nation-state. Since the emergence of the nation-state and subsequently the modern welfare state, the distinction made between citizen and non-citizen has become further intertwined with economic entitlements. Citizenship as social entitlement differs from citizenship as a legal status. Moreover, citizenship as social participation is different from citizenship as political/governance participation.

${ }^{9}$ J. Fudge, "Precarious Migrant Status and Precarious Employment" 110, in reference to Jean Cohen, "Changing Paradigms of Citizenship and the Exclusiveness of the Demos," International Sociology, 1999: 245-268. Cohen also discusses changing paradigms of citizenship for both political democratic citizenship and juridical conception of citizenship.

${ }^{10}$ Bonnie Honig, Democracy and the Foreigner, (Princeton: Princeton University Press, 2003), 54.

${ }^{11}$ Anderson, 2003, 3.

${ }^{12}$ Patrick Wintour, 'David Cameron Shelves Move to Ban British Jihadis Returning to UK' The Guardian 1 Sept 2014.

${ }^{13}$ Joanne Conaghan and Kerry Rittich, Labour Law, Work, and Family: Critical and Comparative Perspectives, (Oxford: Oxford University Press, 2006), 8.
} 
servants,${ }^{14}$ disabled persons,${ }^{15}$ prison inmates ${ }^{16}$ and children. ${ }^{17}$ The experiences of persons designated within these categories further demonstrate that legally possessing citizenship status does not ensure equal recognition of rights in the nation-state. ${ }^{18}$ Citizens throughout history can be 'migrant'. Social and economic inequalities isolate certain sectors of the citizenry, who subsequently are relegated, through the labour market, into situations where their participation as labourers is neither fully inclusive nor exclusive but distanced from the norm. ${ }^{19}$

It is noteworthy as well to identify that the economy is not synonymous with the market, meanwhile both the market (the neoliberal economic market that informs demand in the labour market) and the management of the household (the broader definition of "economy") form inclusions and exclusions within their definitions. For example, the market formally includes the declared legal market that is identified through wage labour and exchange. The economic household includes traditional Western-liberal ideas of household, usually based on a classic model of a nuclear family and male-breadwinner model of employment and income generation through participating in the formal economic market. ${ }^{20}$ However the 'economy' can include a plethora of markets, where market is defined as supply and demand. Citizens considered less-desirable-foreign-born, as well as those not considered to be fully-citizen, able to work (women, children, disabled, criminally convicted, prison inmates)- together with non-national, migrant workers, can be excluded from the community of value while still being included as necessary actors with limited agency in the proto-political, global market economy. These are persons whose subjectivity is incomplete as the included-excluded.

The condition of 'migrant' status is that individuals commonly find work in situations that may be informal, outside recognised employment contracts, with short-term work permits, in seasonal labour, fixed-term contracts or self-employment contracts may fluidly fold into employment practices that are in 'semi-compliance' ${ }^{21}$ with law. Such 'irregular' or exceptional situations serve a particular purpose within the labour market. These workers are characteristically precarious, flexible, non-permanent and often may be hired and fired without any consequences on the employer, where the employment agreement has been arranged outside the operative definitions of employment laws. Particularly if they are non-nationals, persons may be willing to work for cheaper wages, may work in excess of formal working hours, for instance because of temporary stay in the country and a desire to work as much as possible during a limited time. Moreover, if immigration status is precarious, persons may agree to the employers demands to avoid being deported or transgressive of their immigration permit. Those with precarious immigration status are undeniably vulnerable to the worst abuse and exploitation from employers. Nevertheless, citizen workers in low-waged, 'low-skilled' labour sectors may likewise have no choice but to consent to substandard labour conditions.

The uncomfortable -both jurisdictionally and theoretically- intersection of employment and immigration concerns can result in individuals being in the gaps of the law, meaning that their status is ambiguous, in other words irregular. Employing a non-national, migrant labour force can be a way for employers to 'distance themselves [employers] from the moral economy of the labour being done'22,

\footnotetext{
${ }^{14}$ Adelle Blackett, "Emancipation in the Idea of Labour Law" In The Idea of Labour Law, Guy Davidov and Brian Langille, eds., 420-436 (Oxford: Oxford University Press, 2011), 420-21.

${ }^{15}$ JoHn RigG, "Labour Market Disadvantage amongst Disabled People: A Longitudinal Perspective," Centre for Analysis of Social Exclusion, 2005, 2. Also, advocacy groups bring attention to exploitation of persons with disabilities in "sheltered workshops", hospitals, "therapeutic work activities" in institutions: Jihan Addas, "A Legacy of Exploitation: Intellectual disability, unpaid labour and disability services." New Politics 14:1 (Summer 2012), 53.

${ }^{16}$ NoAH ZATz, "Working at the Boundaries of Markets: Prison Labor and the Economic Dimension of Employment Relationships," Vanderbuilt Law Review 61:3 (2008).

${ }^{17}$ Geraldine Van Beuren, The International Law on the Rights of the Child (The Hague: Martinus Nijhoff Publishers, 1998$), 263$.

${ }^{18}$ Anderson, 2013, 4.

${ }^{19}$ JANE Wills, Datta, et al., Global Cities at Work: New Migrant Divisions of Labour (London, New York: Pluto Press, 2010$), 1$.

${ }^{20}$ Judy Fudge, "Labour as a Fictive Commodity," in The Idea of Labour Law Guy Davidov and Brian Langille eds., 120136 (Oxford: Oxford University Press, 2011), 131.

${ }^{21}$ Martin Ruhs and Bridget Anderson. 2010. Semi-compliance and illegality in migrant labour markets: An analysis of migrants, employers and the state in the UK. Population, Space and Place 16(3): 195-21.

${ }^{22}$ Wills Jane, Datta Kavita, Evans Yara et al. 2010. Global Cities at Work: New Migrant Divisions of Labour London New York: Pluto Press.
} 
especially when the work is dangerous, dirty and denigrated (3D's). Employers may feel justified, or less guilty, employing migrant workers who come from regions with less economic opportunities. However, immigration and the economic opportunities for non-nationals is only one part of a system where lowwaged, low-skilled migrant labour is considered problematic. Migrant labour embodies the precaritisation of labour where workers are rendered to the margins of existing labour protections, while serving an increasing demand in the globalised labour market. Restrictions mandated through immigration laws are only one half of the picture in migration and labour, where situations of sub-citizenship are reinforced for those both with and without formal legal citizenship status.

The exclusion of migrant workers from the community of value, and thereby from ready access to legal protections within the nation-state legal system, is not definite. 'Migrant', even where considered irregular, is not 'illegal'. ${ }^{23}$ Catherine Dauvergne, in Making People Illegal, uses the term illegal because of its pointed, specific implication of the law. Dauvergne discusses the process whereby labels "make people illegal" and exacerbate divisions of "us versus them", to contend that the term illegal is the clearest example of this separation..$^{24}$ The term migrant, moreover irregular migrant, does not implicate the law in the way that the term illegal does. Illegal has a direct association with criminality. ${ }^{25}$ Whereas migrant and irregular are now most commonly used to refer to a subset of labourers who are not plainly contravening immigration or labour laws, but nevertheless are marginalized and in the shadow of regulations. Because the term, migrant labour, refers to a broad assortment of employment and migration circumstances, it blurs the distinction between the legal and illegal while reifying the regular citizen labourer as an ideal. An ideal that is infused with assumptions of what constitutes active participation in the nation-state and deserves to be recognised not within the formal legal nation-state, but within a community of shared values.

The definition of migrant in reference to migrant labourer or worker is also unclear. According to the UN International Convention on the Rights of Migrant Workers and Members of their Family (UNCRMW), article 2 (1) defines a migrant worker as 'a person who is to be engaged, is engaged or has been engaged in a remunerated activity in a State of which he or she is not a national. ${ }^{26}$ The International Organisation of Migration (IOM) defines labour migration as 'the movement of people from one country to another for the purpose of employment' but does not define what would constitute employment. The International Labour Organisation (ILO) has defined 'migrant for employment' in Convention No. 97 article 11 (1), as 'a person who migrates from one country to another with a view to being employed otherwise than on his own account and includes any person regularly admitted as a migrant for employment. ${ }^{27}$ The above definitions specifically refer to individuals crossing international borders.

In the UK it is difficult to distil how the popular definition of 'migrant' is applied in data collection and research. The Labour Force Survey (LFS) and Annual Population Survey (APS) are typically used to measure the impacts of migrants on the UK economy and define migrant as 'foreign born'. Based on this definition, calculations of a migrant population would include those who have citizenship and who would not be counted as migrants if 'migrant' were defined as those who are subjected to immigration control or distinguished by self-proclaimed nationality. For data according to National Insurance Numbers (NINo), 'migrant' is defined as a foreign national. However in the Office of National Statistics (ONS), 'migrant' is defined according to the UN definition, where a migrant is someone who is residing in a country other than his or her usual residence for at least a year. ONS data is used in the UK for measuring net migration. Data on net migration have a significant impact on immigration policy and political debates concerning immigration reduction. Yet, the ONS data does not include

\footnotetext{
${ }^{23}$ In fact, the term, irregular, came into popular usage as an alternative to the reference, widely acknowledged as derogatory, of illegal migrants. Migration activists, for example the international movement No One Is Illegal, brought public attention to the derogatory label, illegal. No One Is Illegal (NOII). http://www.noii.org.uk/ (accessed February 13, 2012).

${ }^{24}$ Dauvergne, Making People Illegal, 16-19.

${ }^{25}$ Dauvergne Making People Illegal, 4. The legal ambiguity of the term irregular allows it to be applied to a demographic of labourers beyond a specific legal category.

${ }^{26}$ United Nations International Convention on the Rights of Migrant Workers and Members of their Family, article 2 (1).

${ }^{27}$ The International Labour Organisation (ILO) Convention concerning Migration for Employment (Revised 1949). Entry into force: 22 Jan 1952.
} 
statistics on actual departures from the UK. Length of stay is based on terms stipulated in migrant visas and self-reporting. ${ }^{28}$

The differences in definitions used in UK government surveys are not insignificant. For instance, according to Anderson and Ruhs, if migrants' share of the labour market is a concern for policy makers, that share appears sixty percent larger if one considers all foreign-born workers rather than foreign nationals. In practice, foreign nationals and foreign-born workers have different relationships with the labour market based on whether the intention to stay is permanent or temporary. Temporal restrictions and status concerns for foreign nationals impact the intensity of working hours and length of contract these individuals will agree to. These differences cannot be fairly summarised in most political debates and legal concerns about a migrant labour force. Complications of definitions can be a reflection of the different ways that nationality laws recognise citizenship: jus soli that is citizenship based on birthplace and jus sanguinis, based on nationality of parents. However, politically the use of the term 'migrant' can exploit the inconsistent statistical definitions of migrant to further political agendas. Political discourses significantly impact who is popularly considered to be IML, and consequently treated as a foreigner and non-citizen. Political support for tighter immigration controls obscures the structural labour market (economic) reasons for precarious work as well as the reality of who is carrying out that labour. It is difficult to determine who is a migrant if the term is broadly used to discuss 'foreigners' but evokes flexible, temporary, transient labour.

\section{Precarious employment}

Studies in the UK reveal practices of exploitation and abuse that persist in spite of existing national and international labour standards. ${ }^{29}$ The work produced by these authors contributes to discussions by legal academics that concern the legal, political, economic and social reasons for a category of labourers that are considered to be migrants in irregular situations. ${ }^{30}$ Although there are many connections, the link between being labelled as 'migrant' and precarious work has not been established clearly. Precarious work can refer to a broad range of labour situations, which will be discussed below with regards to subcontracting and fixed-term contracts, whereas migrant labour is commonly associated with low-waged, low-skilled or 'bottom-end', labour. Notwithstanding the absence of a 'robust legal definition of precarious work ${ }^{\prime 1}$ and therefore the possibility that this category also can be used to identify divergent experiences, the concern about migrant workers in the UK indicates possible connections between precarious employment in low-waged low-skilled sectors and a racialised labour force considered to be outside the boundaries of community (national) belonging. The label 'migrant' may be a way to deflect attention from increasing employment precarity as a labour norm, deflecting and deferring national attention to transnational labour concerns and international labour markets. The difficulty in establishing both what constitutes a migrant labourer and precarious work raises the imperative to probe these labels and their function in the UK labour market.

The availability of workers from within the EU, willing to work for less, and a deregulated labour market in the UK promotes a supply in response to a demand for precarious workers. However,

\footnotetext{
${ }^{28}$ Bridget Anderson and Scott Blinder, 'Who Counts as a Migrant? Definitions and their Consequences' (Oxford: Migration Observatory, 2013), pg n/a.

${ }^{29}$ See Maria Hudson, Netto, et al., In-work poverty, ethnicity and workplace cultures, 2013; Working Lives research institute (http://www.workinglives.org) Sonia McKay, Eugenia Markova, and Anna Paraskevopoulou, Undocumented Workers'Transitions: Legal Status, Migration and Work in Europe (London: Routledge, 2011). Research in sociology, see BRIDGET ANDERSON and COMPASS: ANDERSON, "What does 'The Migrant' tell us about the (Good) Citizen?" 2012; public policy: Finch and Cherti 2011; Anderson and Rogaly, Forced Labour and Migration to the UK Study 2005; Geography: Wills, DatTA, et al. Global Cities; politics: McNevin Contested Citizenship, and economics: RuHs, "Towards a post-2015 development agenda: What role for migrant rights and international labour migration?"; DUSTMAN, FABBRI and PRESTON, "The Impact of Immigration on the British Labour Market".

${ }^{30}$ Fudge, "Precarious Migrant Status and Precarious Employment"; GuILD and Mantu, Constructing and Imagining; Davergne Making People Illegal.

${ }^{31}$ SonIa McKaY, "Disturbing equilibrium and transferring risk - confronting precarious work." In Resocialising Europe in a Time of Crisis, Nicola Countouris and Mark Freedland, eds., (Cambridge: Cambridge University Press, 2013), 194.
} 
importantly, the ideal flexible worker does not include workers whose immigration status depends on their employment. For precarious work, 'employers must avoid being tied into sponsorship and other obligations, and [thus they] turn to flexible labour already in the UK.' ${ }^{32}$ Temporary work programmes and the legal employment of third-country nationals are highly regulated. Thus immigration controls 'rather than a tap regulating the flow of workers to a state, ... might be more usefully conceived of as a mould constructing certain types of workers through selection of legal entrants, and the requiring and enforcing of certain types of employment relations. ${ }^{33}$ Citizen workers, especially EU-citizen 'migrant workers' who may be willing to work for less, are left with little choice but to conform to sub-standard employment. Thus in spite of the problem of defining who are migrant labourers and what this label attempts to encompass (and consequentially homogenises), much attention is invested into maintaining a ready supply of workers to fill market demand.

\section{Labour Law and Labour Protection for 'migrant' workers}

The standard employment relationship that developed as a cornerstone of employment law in the UK has been problematised by many labour law scholars to date. ${ }^{34}$ While this standard employment relationship remains entrenched in employment law -as full-time, continuous work, under one employer, with access to employee benefits and entitlements ${ }^{35}$ - in practice it is the employment contract that arguably determines the basis of the employment relationship, granting more flexibility and broader legal scope to contemporary employment situations. ${ }^{36}$ While strides are being made to extend this definition, traditionally labour is recognised by legislated definitions of 'employer' 'worker' 'employee'. ${ }^{37}$ Outside of these definitions it remains difficult to determine a precise contractual employment relationship outside judicial interpretation: from Carmichael to Autoclenz [2011] the definition of employment is being challenged, expanded and interpreted to include the current trends in employment, which include increased prevalence of part-time, fixed-term or casual contracts.

These shifting labour market practices establish precarious work as a new standard for the labour that is demanded across labour sectors and income levels. Leah Vosko defines precarious employment as:

\footnotetext{
'work for remuneration characterized by uncertainty, low income, and limited social benefits and statutory entitlements. Precarious employment is shaped by the relationship between employment status (i.e. self- or paid employment), form of employment (e.g. temporary or permanent, part-time or full-time), and dimensions of labour market insecurity, as well as social context (e.g. occupation, industry, and geography) and social location (or the interaction between social relations, such as gender, and legal and political categories, such as citizenship). ${ }^{38}$
}

Precarious employment is increasingly recognised as a common form of labour, especially in low-waged, low-skilled sectors. ${ }^{39}$ Furthermore, legislation protecting Agency Workers and Part-time Workers is an example of legislative efforts to catch up with shifting labour market practices. Particularly in low-waged, low-skilled labour sectors, the workers who are in precarious employment situations

\footnotetext{
${ }^{32}$ Anderson, Us \& Them, 81 .

${ }^{33}$ Anderson, Us \& Them, 91 .

${ }^{34}$ Mark Freedland and Nicola Kountouris, The Legal Construction of Personal Work Relations (Oxford: Oxford University Press, 2011).

${ }^{35}$ VOSKO 2010, 1.

${ }^{36}$ FreEdLAND and Kountouris, 2011.

${ }^{37}$ Employment Rights Act (ERA) $1996 \mathrm{sec} 230$ (1): an individual who has entered into or works under (or, where the employment has ceased, worked under) a contract of employment. (2) "contract of employment" means a contract of service or apprenticeship, whether express or implied, and (if it is express) whether oral or in writing. (3) "worker" (except in the phrases "shop worker" and "betting worker") means an individual who has entered into or works under (or, where the employment has ceased, worked under) - (a) a contract of employment, or (b) any other contract, whether express or implied and (if it is express) whether oral or in writing, whereby the individual undertakes to do or perform personally any work or services for another party to the contract whose status is not by virtue of the contract that of a client or customer of any profession or business undertaking carried on by the individual.

${ }^{38}$ VOSKO 2010, 3

${ }^{39}$ Fudge 2011a; Vosko 2010; RitTich 2010.
} 
are predominantly non-British nationals. ${ }^{40}$ Migrant, non-British, labour is commonplace in low skilled labour intensive sectors such as agriculture, hospitality and construction where the influx of workers, primarily from the EU, can respond to fluctuating labour demands and seasonal, temporary, contracts. ${ }^{41}$ This has been the case since the development of seasonal worker programmes in the 1950s, and has carried through in times of labour shortages. These sectors are characteristically under-regulated and workers, seasonal workers, are known to be more vulnerable to exploitative practices and abuse from employers. ${ }^{42}$

Currently, a dominant concern is that these previously seasonal arrangements now characterise long-term work arrangements while maintaining a flexible and, for the worker, insecure contractual basis. Workers can be hired and fired on demand by employers who, by forming fixed-term, casual or self-employment contracts are not subject to the same legal obligations that protect employed workers against actions such as unfair dismissal, discrimination and so on. Self-employed workers do have some employment rights, however they are seen as legally more autonomous from the business and contract for services. Therefore, a self-employed worker is seen as someone who is able to substitute their services with another worker, and to maintain full responsibility for paying taxes, being invoiced for their work and establishing the parameters of their work contract. In Autoclenz, the employers argued the labourers were self-employed and therefore, their self-employment status meant that they were ineligible for holiday pay as is granted to employees. The Supreme Court held that the employers were benefiting from sham employment contracts. ${ }^{43}$ The contracts where found to be 'sham' contracts because they identified labourers as self-employed while in practice the labourers were treated as employees of the company.

The decision in Autoclenz demonstrates the potential for judicial decisions to be favourable to precarious workers. By considering the practical relationship underway in Autoclenz, the Supreme Court interpreted an employment contract where contractually there was no such contract of employment. Autoclenz differs from the previous decision in Carmichael $v$ National Power plc [2000], where it was decided that there was no obligation clause in the contract between Carmichael and her employers. Carmichael's work arrangement was 'casual', and it was held that casual workers lacked a relationship of 'mutuality of obligation' with the business. Consequently, there was no contract of employment and therefore the workers were not entitled to the written terms of a contract of employment. ${ }^{44}$

${ }^{40}$ Wills Jane, Datta Kavita, Evans Yara et al. 2010. Global Cities at Work: New Migrant Divisions of Labour London New York: Pluto Press.

${ }^{41}$ AndERSON and RuHS, 2012.

${ }^{42}$ Since SAWS, seasonal workers programmes are characteristically intensive, demanding and brutal. The discursive identification of a low-waged labour force as foreign workers currently remains in the UK as one that was rooted in seasonal migrant worker programmes, but has since developed into anti-European Union scare-mongering. In the UK, the label 'migrant' may refer to persons who are on temporary or short-term work visas, who are actually dealing with immigration law provisions, as well as EU nationals who, due to EU freedom of movement (Directive 2004), do not require work visas.

${ }^{43}$ Alan Bogg and Tonia Novitz. 2013. Race discrimination and the doctrine of illegality Law Quarterly Review. 129: 12-17.

${ }^{44}$ In Consistent Group v Kalwak [2008] EWCA Civ 430, the question considered in the Court of Appeal after the Employment Tribunal was whether claimants were employees employed by Consistent Group Limited, whether they were also 'workers', and whether they were employees, workers or neither of Welsh Country Foods Limited (WCF), and whether the 'Obligations' term in their contract of employment was a sham or not. If the 'obligations' part of the contract was found to be a sham, then this would mean that 'both parties intended to paint in that respect a false picture as to the true nature of their respective obligations.' (at para 28). It was held in the Court of Appeal that there was no obligations clause in the employment relationship with Consistent Group because the relationship lacked 'mutuality of obligation' to be a contract of employment (152-153). According to Lord Justice May, "the written contract between each other claimants and Consistent expressly purported to be a self-employed subcontractor's contract for services. The 'Obligations' clause, ..., taken at face value ... would not constitute the claimants as employees for the purpose of section 230 of the Employment Rights Act 1996.” (at para 55). In Carmichael v National Power plc [2000] IRLR 43 it was affirmed that in agency work, there can be found to be a lack of mutuality and therefore no general contract of employment, when casual workers have the option to refuse work, as well as a discontinuous contractual relationship (the difference in obligation between when work was offered and when working was seen to demonstrate that the parties were not in a relationship of continuous employment). However in Autoclenz Limited v. Belcher and others [2011] UKSC 41, it was established that where 'written documentation may not reflect the reality of the relationship' (at para 22 Lord Clarke), there is possibility to find the contract a sham employment contract. In Autoclenz, even though the terms of the contract explicitly stated that the workers were self-employed, the practice of services demonstrated that the contract was in reality one of employment. 
Concerns for precarious employment in the UK, in low-waged or 'bottom-end' labour, intersect with concerns for persons working with precarious immigration status. In the UK, the presence of European Union citizen workers has spurred political fervour against UK's membership in the EU, particularly due to the EU Directive on freedom of movement for labour. ${ }^{45}$ Migrant labourers from within the EU -mainly those who are nationals of financially weaker countries, frequently referred to as persons from the Eastern European bloc-are blamed for driving down wages and limiting employment opportunities for British workers. ${ }^{46}$ Firstly, there is a clear lack of evidence to support these claims. ${ }^{47}$ Secondly, the rhetoric in popular media and political discussions confuse immigration status and immigration policy with shifts in labour market demand. 'Irregular' labour situations and a downward pressure on wages and/or employment opportunities are not directly a consequence of immigration law and workers with precarious immigration status. Notwithstanding the increased vulnerability of persons whose precarious immigration status and threat of detention/deportation can be used to exploit their labour mentioned above, the de-regulation of labour standards, the current labour market demand and employment practices that seek out precarious work arrangements are not solely based on their immigration (visa) status. In order to address the current fears of migrant labour in the UK it is necessary to look not only at the exploitation of non-nationals in labour situations that take advantage of their precarious immigration status, but also at how poverty is exploited such that workers consent to increasingly precarious work, thus contributing to a downward pressure on wages that is connected to the demands of a globalised economic market for cheap flexible labour within a deregulated labour market.

A de-regulated, or un-checked, labour market is a concern that extends beyond the immediate situation of migrant labour and precarious employment. Labour law scholars, notably Bob Hepple, have identified a general lack of political will and political culture in the UK to intervene in employment and business practices. ${ }^{48}$ The demand for flexible, precarious workers whose employment situations exceed the scope of legislation meant to enforce minimum protections and rights for workers do not raise alarm when these protections and rights are seen to impede economic priorities of fostering economic growth and maintaining global market competitiveness. As is widely recognised, especially in times of economic crisis or recession governments lessen the protective regulatory function of labour and employment laws. An on-going demand for cheap and flexible labour sustains lower production costs and conceivably, greater economic output. Economic growth is measured against a supposedly global economic market and is privileged at the expense of employment security and labour protection.

Immigration policies prioritise an employer-led, flexible system, 'responsive to market needs'49 above labour protection. This was emphasised since in 2002, the Points-Based System (PBS) was introduced. The PBS obliges all applicants below Tier 1 (highly skilled work permits) to apply via a UK sponsor. The employer-sponsor is responsible for the migrant - for their entry requirements and, more importantly, for their exiting the country according to the conditions of their work permit. ${ }^{50}$ This shift abrogated government oversight over immigration work permits and opened the potential for businesses to benefit from cheaper labour, which government emphases as beneficial for the national economy. However, sponsorship has also increased the potential that workers will be exploited. Workers are bound to particular employers for their legal right to be in the country and thus without recourse to seek safer, or non-abusive employment. ${ }^{51}$ As an example, in 2003 in Morecambre Bay, UK, migrant labourers

\footnotetext{
${ }^{45}$ Most notably, UKIP

${ }^{46}$ UKIP blames immigration for labour market shifts and global economic changes (global supply chains etc).

${ }^{47}$ Dustmann Nov. 2014

${ }^{48}$ Boв Hepple 2013. Also, 'Present day governments are reluctant to interfere with flexibility [freedom of contracts] for fear that restrictions might damage the competitiveness of business.' (Hugh Collins 2010, 187). Lack of regulation means more irregular workers.

${ }^{49}$ UK Border Agency, Controlling Our Borders: Making Migration Work for Britain (2005) Cm 6472:15.

${ }^{50}$ In 2005, unemployment (UE) was at a historic low and there seemed to be a genuine economic need for migrant workers, particularly in the service sector. In spite of this need, as mentioned above in text, it was recommended that low-skilled work permit schemes (Tier 3 ) be phased-out within three years due to the availability of a labour supply from the EU. Accordingly, Tier 3 was phased-out by 2008, except for A2 migrants, from Romania and Bulgaria.

${ }^{51}$ Bridget Anderson, “Illegal immigrant”: Victim or Villain?' Centre on Migration, Policy and Society Working Paper. University of Oxford 64 (2008).
} 
working as cockle pickers were tragically swept into the sea. An investigation into their deaths revealed gangmaster work practices. ${ }^{52}$ Consequently, the government created the Gangmasters Licensing Authority and Act of 2004. The 2004 Asylum and Immigration (Treatment of Claimants etc.) Act and, separately, the Gangmasters (Licensing Authority) 2004 Act (GLA) addressed unregulated employment and situations whereby employers knowingly employ illegal workers by introducing workplace inspections and spot fines for employers using illegal workers. ${ }^{53}$ The 2004 Act and the GLA were specifically meant to respond to gang labour, which as form of employment facilitates a flexible labour supply that is mostly filled by migrants from EU countries. According to Kendra Strauss, 'many gang workers are economic migrants from the EU accession countries, recruited in their country of origin by local labour intermediaries, while some ... are undocumented workers who become enmeshed in local networks of non-British labour contractors. ${ }^{54}$ Many migrant advocates and workers welcomed the intervention made by the GLA in 2004. However, the GLA focuses only on particular labour sectors, excluding labour that is self-employed or agency work. Consequently, much of the on-going exploitation experienced by precarious labourers occurs beyond the scope of this legislation. The GLA also suffers from a severe lack of funds and resources. This has rendered the GLA limited in its success and scope..$^{55}$ In spite of the GLA's mandate to regulate employers and the Points Based System (PBS) formalising work permits, the demands in employment that maintain irregular and exploitative labour practices exceed existing regulations. Moreover, the lack of political will to allocate funds to the GLA reinforces the political priority to maximise profit and minimised regulation. The Points-Based System has made the process of acquiring legal permission to migrate and sponsor migrants more difficult, and the number of persons coming in from non-EEA countries to work in low-skilled/ low-wages occupations has decreased. Meanwhile the standards, wages and conditions in the labour sectors have not improved. ${ }^{56}$ Neither the PBS nor the GLA eliminated precarious employment, where this type of employment is kept off record. Employers may extend working hours, withhold pay, or require workers to work overtime without pay, all the while appearing to give their workers autonomous choice to consent or refuse. Employers are able to manipulate terms of employment that defer their responsibility, for example when labourers are technically selfemployed or sub-contracted through an agency. In these cases, the employer is not necessarily bound to protect the workers through existing company regulations or policies. ${ }^{57}$

\section{Conclusion: migrant labour and the future of labour law}

The aforementioned community of value promises to fulfil the 'spirit' of a 'people' within a shared, cohesive and known shared set of values. In the UK, as Anderson argues, the community of value is 'populated by 'good citizens', law-abiding and hard-working members of stable and respectable families. ${ }^{58}$ Membership in the community of value is afforded to these Good Citizens who reflect liberal ideas (autonomy, freedom, belonging and property, are British, educated, predominately male, middle (to upper) class. This membership is protected and restricted, even against legal (formal) citizenship categories - which is how the exploitation of precarious workers in low-waged and low-skilled labour (the downward pressure on their wages and tendency towards casual, insecure work contracts) continues

\footnotetext{
${ }^{52}$ Gang labour is 'a form of temporary casual labour in which an agent ('gangmaster') contracts and supplies workers for employment in the British labour market, traditionally in the horticultural and agricultural sectors.' Kendra Strauss, "Unfree again: social reproduction, flexible labour markets and the resurgence of gang labour in the UK," Antipode 11 (2012): 1-18.

${ }^{53}$ Gangmasters Licensing Act 2004 ch.11; Gangmasters Licensing (Exclusions) Regulations of 2006, S. I. 2006/ 658). The GLA (2004) was established after the deaths of migrant labourers (cockle-pickers) in Morecambre Bay, UK. BBC News, "Tide kills 18 cockle pickers" BBC News February 6, 2004.

${ }^{54}$ Strauss, "Unfree again" pg. n/a.

${ }^{55}$ WILKINSON 2012, 15-17.

${ }^{56}$ UK Home Office, Managing Migration: The Points Based System, Select Committee on Home Affairs report July 2009 , Thirteenth Report of Session HC 217-1 (2008-2009).

${ }^{57}$ Anderson and Ruhs, Who Needs Migrant Workers?, 13. A more detailed discussion of employment law will follow in chapter four.

${ }^{58}$ Anderson, Us \& Them, 3.
} 
even for labourers who are British Citizens. ${ }^{59}$ This while the 'community of value' is not written in to legislation per se, the values guide political priorities, labour enforcement or their non-enforcement, as is the case with the GLA 2004.

My conclusion is not a closing but instead leaves with a suggestion for where this discussion of migration labour and labour law may lead. Labour law scholarship is currently concerned with the contemporary relevance of existing legal frameworks and legal fields. ${ }^{60}$ Ostensibly 'global' labour markets depend on an increasingly precarious supply of workers across labour sectors and employment. Maintaining a focus on migrant labour that is considered 'irregular', I suggest that re-thinking law and the legal citizen-subject might be necessary before possible remedies available for 'irregular' migration and their precarious employment situations to be widely successful. Such a deeper questioning suggests looking at how labour market economic concerns converge with ideas of citizenship and who is permitted recognition as a legal subject.

Philosopher Jean-Luc Nancy offers a concept of the confronted community to re-consider how what is experienced, included and excluded, within law and labour markets exceed existing categories of labour law through frames of immigration and citizenship. Being identified as a 'migrant' suggests that ones presence is not one of permanent belonging but rather exists (is present) in legal grey areas in the shadow of the domestic law. In his work, Nancy explores the presence of persons interacting and relating in spite of formal inclusions or exclusions. ${ }^{61}$ Our very basic being is relational, and from this sociality of interaction, we have what we know of as our economic, legal and political infrastructures. The bare relationality that constructs the matter of society (economic, juridical and political) is not a utopian community, but rather is the bare bones or foundation of what constitutes our world. This 'originary' or basic interaction, according to Nancy, comes before categories and labels that ascribe meaning and recognition in relation to the nation-state and its legal system. Nevertheless, in the coming together the only language that we have and know is within the frame of the nation-state and traditional law. Therefore, if unquestioned, the economy and the labour markets that are managed through legal frameworks are produced, reproduced and perpetuated.

Nancy's work offers a unique approach to the analysis of labour law and migrant labour by suggesting a starting point that strips legal categories bare to expose the actual practices of sociability and labour production and reproduction. Without attention to the constructed categories, labour is predetermined into categories that render some persons 'irregular' against a presumed 'regular' ideal citizensubject. When unquestioned, the sociality is understood only from a paradigm of thought that not only is traditional labour law, but more fundamentally remains contingent on a historically specific system of political and juridical governance, constructed through modern philosophy's understanding of being and from this, legal status. The political-juridical governance structure informs language, categories and knowledge. This, the Western, modern-colonial philosophical tradition, is not only a lasting ideological foundation of current legal categories and subjectivities, but has capitalised on the epistemological and ontological facets of law's origins and our very social, political, economic constitution. For this reason, the legal grey areas where persons in 'irregular' labour situations are not only in the gaps of 'regular' legal status, but are the irregular against which the subject is constituted as regular. In spite of the sociality including the labour (production and reproduction) of all actors, in Nancy's words the 'originary sociality' that is the basis of our society and economy, legal categories differentiate regular citizen subjects from those considered to be irregular. This is crucial to analyse because the legal categories do not negotiate a border of legal versus illegal. Rather the difference is more ambiguous, and legal grey areas more elusive. For this reason, my approach deeply questions how we constitute being as a person subjected under the law.

\footnotetext{
${ }^{59}$ According to Bonnie Honig, membership in a nation-state through citizenship is not a matter of legal techniques and requirements; it is based on conditions of desirability. These conditions make membership for some impossible (Honig 2001, 54). Precarious labourers are kept beyond the scope of legal regulation and active citizenship participation within a national legal system. Meanwhile, their labour benefits a national (domestic) economy.

${ }^{60}$ Many scholars are exploring new conceptual and regulatory possibilities in labour law (Freedland and Kountouris 2012; Arthurs 2011, 22; Fudge 2011b, 128-135; Zatz 2011, 234; Blackett 2011, 434-436); Migrants at Work

${ }^{61}$ Jean-Luc Nancy, An Inoperative Community Minnesota: University of Minnesota Press, 1991.
} 
The direct applicability of connecting migration and labour law concerns with fundamental questions of being via the constitution of sociality remains undetermined in my analysis. However, my approach to labour migrants in irregular situations and their troubled access to recognition under labour/ employment laws begins from the fundamental question of why formal categories of labour and employment law are insufficient to remedy the situation of 'irregular migrant labourers'. Digging into this question brings me to consider how persons are constituted and recognised as legal subjects. By using this as a starting point, further work aims to unravel the present inability for existing legal systems and instruments to adequately address persons living and working in the shadows of the law.

Shifting epistemologically our understanding of citizenship and labour market participation and labour to the confronted community would open onto the multiple practices and experiences of labour and work and place labourers not as occupying legal grey areas but as confrontation of a globalised labour market demanding cheap labour. This would enable a critical intervention into broader, overarching, labour and economic practices that go un-examined in the immediate concerns of labour regulations and enforcement of existing legislative protections. 